\title{
DEVELOPMENT OF A MICROWAVE-ASSISTED UV STERILIZATION SYSTEM FOR MILK
}

\author{
S.S. Singh, S. Mishra*, R.C. Pradhan and K. Vivek \\ Department of Food Process Engineering, \\ National Institute of Technology, Rourkela, Odisha, India
}

(Received: 4 December 2017; accepted: 15 February 2018)

\begin{abstract}
A microwave-assisted ultraviolet sterilization system was developed to study the synergistic effect in the sterilization of milk. Electrodeless lamps emitting ultraviolet radiation inside the microwave chamber gave a synergistic effect without challenging food safety standards. This study compared the results of both microwave and microwave assisted ultraviolet sterilizations of milk in terms of various microbial tests and physicochemical properties. The microwave-assisted ultraviolet system was found to be more effective compared to microwave alone. A significant difference $(\mathrm{P}<0.05)$ was observed for total plate count and methylene blue reduction test between microwave and microwave assisted ultraviolet treatment from 5 to $15 \mathrm{secs}$. Microwave-assisted ultraviolet treatment decreased the microbial count exponentially and showed $<1 \log \left(\mathrm{CFU} \mathrm{ml}{ }^{-1}\right)$ after ten seconds of treatment. During the treatment period, no significant difference was observed in the physicochemical properties of milk.
\end{abstract}

Keywords: microwave, electrodeless lamp, ultraviolet, microbial tests, physicochemical properties

Milk is almost a complete food with all the essential nutrients and is highly susceptible for microbial spoilage. Different thermal treatments as pasteurization, ultra-high temperature sterilization (UHT), thermization, and innovative steam injection treatment (ISI) have been used to protect milk from microbial spoilage with different temperature-time combinations (Claeys et al., 2013; Ion-TitaPicColo et al., 2013). However, these thermal treatments result in nutrients degradation. Sterilization of milk makes the product safe with longer shelf life. Conventional thermal treatment of milk degrades amino acids resulting in off-flavour and changes in $\mathrm{pH}$ and colour (SIEBER et al., 1996). Therefore, it is required to develop alternative non-thermal sterilization techniques that would preserve nutrients. Application of microwave, ultraviolet (UV) light, and ultrasound has been explored for sterilization of various liquid foods with some positive results (Kindle et al., 1996; Ion-Titapiccolo et al., 2013; TANG, 2015). Microwave heating works superior to conventional heating, and reduces the treatment time significantly. Microwave pasteurisation and sterilisation preserve quality due to lower thermal exposure. It requires less time to inactivate enzymes and most heat-resistant microbes. Vitamin (B1, B2, and B6) retention in microwave-treated milk is higher (GÉCZI et al., 2013).

UV radiation can be generated by an electrodeless lamp powered by the electromagnetic waves generated by microwaves at the frequency of $2450 \mathrm{MHz}$. UV treatment of food is a USFDA and USDA approved method. USFDA has defined a performance criterion for UV processing of vegetables and fruit juices to a 5-log reduction for different target microorganisms (IwAGUCh et al., 2002; KeYser et al., 2007). UV treatment is effective and non-toxic in nature. UV radiation has lower penetration depth and, hence, is good for surface sterilisation only.

\footnotetext{
* To whom correspondence should be addressed. Phone: 0661-2462905; email: mishrasa@nitrk1.ac.in
} 
Effectiveness of UV is also limited to organic solutes, suspended particles, and colour compounds of the juice (Keyser et al., 2008; Koutchma, 2008; Falguera et al., 2011). Therefore, standalone application of UV is not recommended. Combination of both microwave and UV has higher efficiency in reducing microbial load exponentially in wastewater treatment (MISHRA et al., 2010). This combination can very well be explored to find the synergistic effect on microbial load and quality parameters of milk by developing a microwave-assisted ultraviolet sterilization (MWUV) system.

\section{Materials and methods}

\subsection{Materials}

Raw cow milk was procured locally in Rourkela, Odisha, India. Microbial load and other quality of the raw milk were analysed. The raw milk was then treated with microwave alone and with microwave assisted UV light at different time intervals $\left(\mathrm{T}_{\mathrm{n}}\right)$ of $5,10,15$, and 20 seconds. The treated samples were analysed for microbial and quality parameters such as total plate count (TPC), coliforms enumeration, methylene blue dye reduction test (MBRT), colour, total soluble solids (TSS), and $\mathrm{pH}$ before and after treatments. A process flowchart for the work done has been shown in Figure 1.

Experimental flow chart

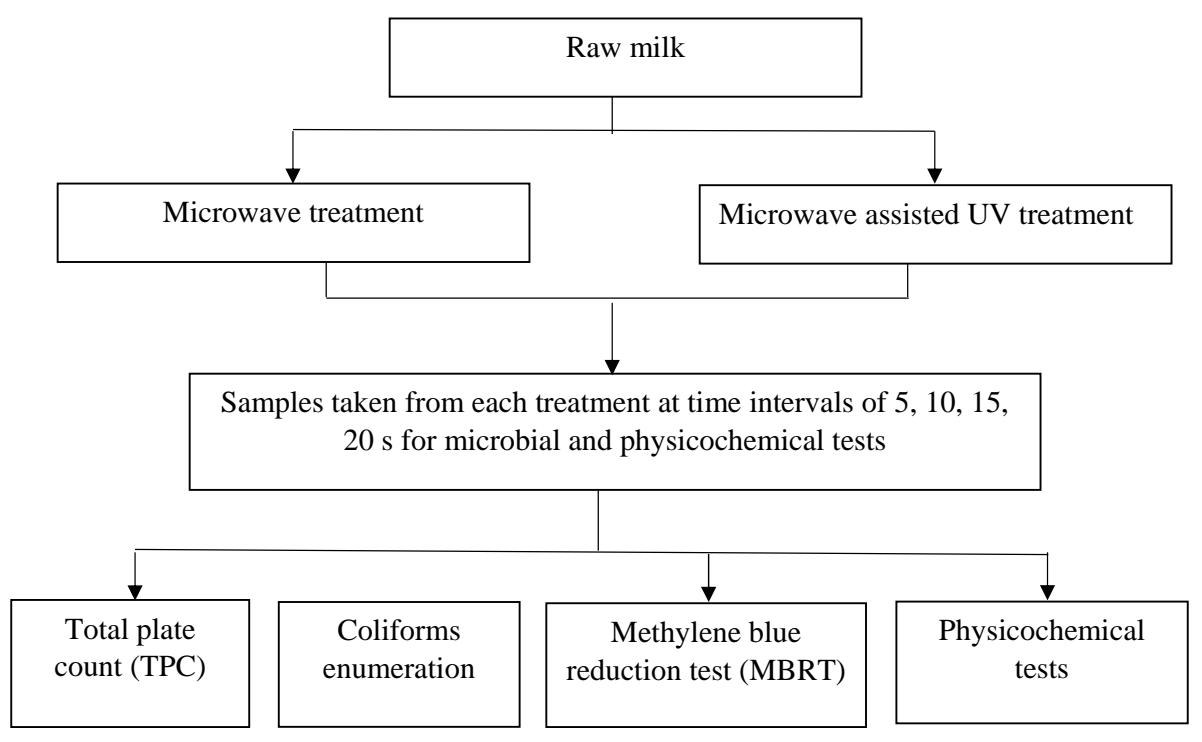

Fig. 1. Experimental process flow chart for the sterilization process of milk 


\subsection{Development of microwave assisted UV sterilization system}

A domestic microwave oven $(2450 \mathrm{MHz}, 1200 \mathrm{~W})$ was modified as per need. Two holes $(5 \mathrm{~mm})$ were drilled in the ceiling of the microwave for two Teflon pipes (inlet and outlet). The holes were sealed properly with Teflon adhesive to prevent radiation leakage. The pipes were connected to a peristaltic pump. The volumetric flow rates in inlet and outlet pipes were kept constant (Fig. 2). The speed of the pump (80 to 120 r.p.m.) was adjusted for a continuous flow of sample to the sample holder. The microwave treatment was started after achieving the constant level of the sample inside the sample holder $(250 \mathrm{ml})$. The outlet pipe was connected to a stainless steel (SS) cooling coil (length $2 \mathrm{~m}$, diameter $4 \mathrm{~mm}$ ) to release the heat generated during microwave treatment. Water at $20 \pm 2{ }^{\circ} \mathrm{C}$ was used as coolant.

The electrodeless lamps (Part No. 558432, H-Type, Albatross UV, USA) were kept inside the sample holder. The lamps were $152.4 \mathrm{~mm}$ long with $9 \mathrm{~mm}$ diameter. The rated power output was $11.81 \mathrm{~kW} \mathrm{~m}^{-1}$. The specified UV wavelength ranged between 254 to 365 $\mathrm{nm}$, which is effective in sterilisation. The electrodeless lamps absorb microwaves and emit UV radiations in the sample holder (MАKTABI et al., 2011). A schematic diagram of the developed MWUV system is given in Figure 2.

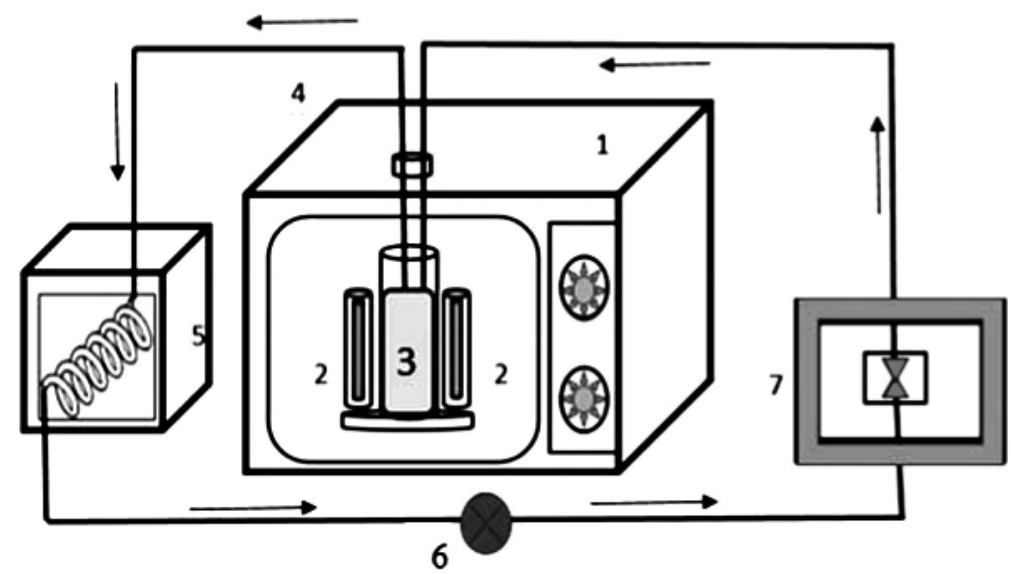

Fig. 2. Line diagram of experimental set-up

(1) : Microwave oven; (2): Electrodeless UV lamp; (3): Reactor ; (4): Teflon pipes; (5): Cooling chamber;

(6): Sample collector; (7): Peristaltic pump

\subsection{Methods}

1.3.1. Methylene blue reduction test (MBRT). MBRT is the most common and rapid method for determining the quality of milk in India. It examines the microbial quality of raw and pasteurized milk. This test is based on the fact that the blue colour of the dye solution added to the milk gets decolourized when the oxygen present in the milk is exhausted due to microbes. The sooner the decolourization the more inferior the quality of the milk. Milk samples $(10 \mathrm{ml})$ were added with $1 \mathrm{ml}$ of blue dye in sterile test tubes. The test tubes were clogged well to cut off the oxygen, and placed in a water bath at $35 \pm 1{ }^{\circ} \mathrm{C}$ for 7 hour (CHEN et al., 2004; Aglawe \& WADATKAR, 2012). Results were analysed as per the standard MBRT chart. 
1.3.2. Enumeration of coliforms. MPN method is used to quantify the concentration of viable microorganisms (mainly coliform bacteria) in the sample with the help of replicate liquid broth in ten-fold dilutions. MacConkey broth (Himedia, India) with composition of peptic digest of animal tissue (40.0), lactose (20.0), bile salts (10.0), sodium chloride (10.0), neutral red (0.14), final $\mathrm{pH}$ (at $25^{\circ} \mathrm{C}$ ) $7.5 \pm 0.2$ per litre, was used for the analysis. Then the medium and glassware were autoclaved at $121{ }^{\circ} \mathrm{C}(103.42 \mathrm{kPa}$ pressure) for $15 \mathrm{~min}$. Inoculated tubes were incubated at $37 \pm 1{ }^{\circ} \mathrm{C}$ for $24 \mathrm{~h}$. After $24 \mathrm{~h}$, the presence of gas is indicated by bubbles collected in the tube and the acidity is indicated by the colour change in the medium (Novak \& Almeida, 2002; Bienvenue et al., 2003). The results were analysed with reference to the standard MPN chart.

1.3.3. Total plate count (TPC). It is commonly used to quantify the total number of viable bacteria in food. Bacteria present in food form colonies when a nutrient medium is provided, which can be counted to find the number of cells in the sample. The results are expressed as the number of colony forming units (CFU) per $\mathrm{ml}$ of the sample (CFU ml $\left.\mathrm{m}^{-1}\right)$. Nutrient agar was taken as a medium supporting the growth of different types of bacteria. The plates were kept aerobically in an incubator at $35 \pm 1^{\circ} \mathrm{C}$ for $48 \mathrm{~h}$ (ANDERSON et al., 2011; BANIK et al., 2015). The bacterial colonies were counted in digital colony counter.

\subsubsection{Physico-chemical characteristics}

1.3.4.1. Colour. The colour of the raw milk, as well as the treated milk, were measured by a colorimeter (ColourFlex-EZ, Hunter Lab, USA) in terms L, a, and b. It uses a xenon flash lamp to illuminate the sample and the reflected light at different wavelengths (visible 400-700 nm) are analysed to give the colour values of the sample in numeric value (PopovRALJić et al., 2008; SHEKHAR et al., 2012). "L" denotes lightness and ranges from 0 (black) to 100 (white); "a" denotes redness when positive and greenness when negative; and "b" denotes yellowness when positive and blueness when negative.

1.3.4.2. $\mathrm{pH}$ measurement. A digital $\mathrm{pH}$ meter (PHS-2F, Harris, England) was used to measure the $\mathrm{pH}$ of raw and treated milk. The $\mathrm{pH}$ meter was standardised using buffer solutions of $\mathrm{pH} 4.0$ and 7.0. A sample volume of $50 \mathrm{ml}$ was used for $\mathrm{pH}$ measurement by immersing the $\mathrm{pH}$ probe into the sample (OMOARUKHE et al., 2010; ON-Nom et al., 2010). All measurements were done in triplicates. The $\mathrm{pH}$ values of samples were compared before and after the treatments.

1.3.4.3. Total soluble solids (TSS, ${ }^{\circ}$ Brix). A hand-held digital refractometer (MASTER$\mathrm{S} 10 \mathrm{a}$, India) was used to measure the TSS of raw as well as the treated milk samples. A small amount of the sample was dropped on the glass prism of the refractometer. The TSS ( ${ }^{\circ}$ Brix) readings of the samples were noted for further analysis (BIENVENUE et al., 2003; ON-Nom et al., 2010).

\subsection{Statistical analysis}

All experiments were done in triplicate and statistically analysed with ANOVA and paired sample t-test using SPSS (Version 20.0, IBM Corporation, USA), and the differences in mean values were denoted by levels of significances $(\mathrm{a}-\mathrm{e})$ at $\mathrm{P}<0.05$. 


\section{Results and discussion}

\subsection{Methylene blue reduction test (MBRT)}

For MW treatment, it was found that MBRT time increased as the treatment time increased from 5 to $10 \mathrm{~s}$. Significant differences $(\mathrm{P}<0.05)$ were observed between 0 and $5 ; 5$ and 10 ; and 15 and $20 \mathrm{~s}$. But between 10 and $15 \mathrm{~s}$, no significant difference $(\mathrm{P}>0.05)$ was observed. Similar result was obtained for MWUV treatment (Table 1). The increase in MBRT time may be due to the bactericidal effect of UV (ANDERSON et al., 2011). It was found that $15 \mathrm{~s}$ was sufficient to get the milk sterilized in MWUV.

Table 1. Comparison of MBRT values of microwave (MW) and microwave assisted ultraviolet (MWUV) treatments

\begin{tabular}{lccc}
\hline Sample No. & MBRT time for MW (min) & MBRT time for MWUV (min) & P-value \\
\hline $\mathrm{T}_{0}$ & $85^{\mathrm{a} 1}$ & $86^{\mathrm{a} 1}$ & 0.251 \\
$\mathrm{~T}_{5}$ & $147^{\mathrm{a} 2}$ & $154^{\mathrm{b} 2}$ & $0.002^{*}$ \\
$\mathrm{~T}_{10}$ & $225^{\mathrm{a} 3}$ & $312^{\mathrm{b} 3}$ & $0.000^{*}$ \\
$\mathrm{~T}_{15}$ & $233^{\mathrm{a} 3}$ & $413^{\mathrm{b} 4}$ & $0.000^{*}$ \\
$\mathrm{~T}_{20}$ & $418^{\mathrm{a} 4}$ & $422^{\mathrm{a} 4}$ & 0.165 \\
\hline
\end{tabular}

Note: All values are mean values; all experiments were performed in triplicate; $a, b$, indicate significant differences by treatment times along the row; 1, 2, 3, 4 indicate the significant differences along column; $p$-value corresponds to probability of occurrence given by one-way ANOVA; * represents significance at level $\mathrm{P}<0.05$.

\subsection{Enumeration of coliforms}

Both microwave (MW) and microwave-assisted UV (MWUV) treatments showed less coliform presence till treatment time of $\mathrm{T}_{10}$ for MW and $\mathrm{T}_{5}$ for MWUV (Table 2). Further increase in treatment times of both MW and MWUV milks showed absence of coliform. This is under the accepted limit of American Public Health Association (APHA, 1995). The combination of MW and UV in the MWUV treatment from $\mathrm{T}_{5}$ till $\mathrm{T}_{10}$ had a synergistic effect that sterilized the sample at a faster rate without deteriorating the natural properties of the milk. When microorganisms are exposed to UV radiation, cellular purines and pyrimidine bases of DNA absorb the energy and are damaged. Hence, the microbes are killed (VANDERZANT \& Splittstoesser, 1992; Chye et al., 2004).

Table 2. Most probable number (MPN) for microwave (MW) and microwave assisted UV (MWUV) treatments of milk

\begin{tabular}{|c|c|c|c|c|c|c|c|c|c|c|c|c|}
\hline \multirow[t]{2}{*}{ Sample } & \multicolumn{2}{|c|}{$\mathrm{DS}(0.1)$} & \multicolumn{2}{|c|}{$\mathrm{SS}(0.01)$} & \multicolumn{2}{|c|}{ SS $(0.001)$} & \multicolumn{2}{|c|}{$\mathrm{MPN} \mathrm{ml}^{-1}$} & \multicolumn{2}{|c|}{ Low } & \multicolumn{2}{|c|}{ High } \\
\hline & MW & MWUV & MW & MWUV & MW & MWUV & MW & MWUV & MW & MWUV & MW & MWUV \\
\hline $\mathrm{T}_{0}$ & 3 & 3 & 3 & 3 & 2 & 2 & 1100 & 1100 & 180 & 180 & 4100 & 4100 \\
\hline $\mathrm{T}_{5}$ & 3 & 3 & 3 & 2 & 2 & 2 & 1100 & 210 & 180 & 40 & 4100 & 430 \\
\hline $\mathrm{T}_{10}$ & 2 & 1 & 0 & 1 & 0 & 0 & 9.2 & 7.4 & 14 & 1.3 & 38 & 20 \\
\hline $\mathrm{T}_{15}$ & 2 & 0 & 1 & 0 & 1 & 0 & 2.0 & $<3.0$ & 4.5 & - & 42 & 9.5 \\
\hline$\underline{T}_{20}$ & 1 & 0 & 0 & 0 & 0 & 0 & 3.6 & $<3.0$ & 0.17 & - & 18 & 9.5 \\
\hline
\end{tabular}

Note: All the values are compared from the standard MPN table; DS: double strength; SS: single strength. 


\subsection{Total plate count (TPC)}

As the treatment time increased, the TPC decreased for both microwave (MW) and microwave-assisted UV (MWUV) treatments up to $T_{15}$. A significant difference $(P<0.05)$ was observed between all treatment times for both MW and MWUV. In case of MWUV, the microbial load was minimal after $10 \mathrm{~s}$, whereas a considerable amount of microbial load was found in MW treated sample at the same time. MW treatment of milk reduced almost $3 \log$ cycles, i.e. from $\log 5.387$ to $\log 2.23$, after $20 \mathrm{~s}$ of treatment, whereas MWUV treatment reduced up to $5 \log$ cycles (from $\log 5.408$ to $<1 \log \left(\mathrm{CFU} \mathrm{ml}{ }^{-1}\right.$ ) (Table 3). Better sterilization by MWUV may be due to the extra stress added by the UV radiations. The results obtained from this technique of sterilization meet the World Food Programme Standard (KоuтснмA, 2008). Thus, MWUV sterilization can be considered as an alternate efficient sterilization method for liquid foods.

Table 3. Mean values of total plate count (TPC) comparison for microwave (MW) and microwave assisted UV (MWUV) treatments

\begin{tabular}{lccc}
\hline Sample No. & $\begin{array}{c}\text { TPC for MW } \\
\left(\log \left(\text { CFU ml } l^{-1}\right)\right)\end{array}$ & $\begin{array}{c}\text { TPC for MWUV } \\
\left.\left(\log (\text { CFU ml })^{-1}\right)\right)\end{array}$ & P-value \\
\hline $\mathrm{T}_{0}$ & $5.40^{\mathrm{a} 1}$ & $5.41^{\mathrm{a} 1}$ & 0.23 \\
$\mathrm{~T}_{5}$ & $3.70^{\mathrm{a} 2}$ & $3.10^{\mathrm{b} 2}$ & $0.00^{*}$ \\
$\mathrm{~T}_{10}$ & $3.12^{\mathrm{a} 3}$ & $2.33^{\mathrm{b} 3}$ & $0.00^{*}$ \\
$\mathrm{~T}_{15}$ & $2.31^{\mathrm{a} 4}$ & $<1.00^{\mathrm{b} 4}$ & $0.00^{*}$ \\
$\mathrm{~T}_{20}$ & $2.23^{\mathrm{a} 4}$ & $<1.00^{\mathrm{b} 4}$ & $0.00^{*}$ \\
\hline
\end{tabular}

Note: All values are mean values; all experiments were performed in triplicate; ${ }^{\mathrm{a}, \mathrm{b}}$ : indicate the significant differences by treatment time along the row; ${ }^{1,2,3,4}$ : indicate the significant differences along column; P-value corresponds to probability of occurrence given by one-way ANOVA; * represents significance at level $\mathrm{P}<0.05$.

\subsection{Analysis of physicochemical properties}

Various physicochemical properties, like $\mathrm{pH}$, colour, and TSS, were measured for both MW and MWUV treatments (Table 4). There were significant $(\mathrm{P}<0.05)$ differences in $\mathrm{pH}$ values of MW treated samples for all treatment durations. This may be due to the reduction of water content in milk due to microwave heating, thus increasing the concentration of minerals compared to untreated milk (WALSH et al., 1998; BIENVENUE et al., 2003). Similarly, colour and TSS were also statistically analysed at $\mathrm{P}<0.05$. TSS increased due to decrease in water content of the milk during treatment (SheKhAR et al., 2012). Significant $(\mathrm{P}<0.05)$ differences were observed for all treatment times for MW and MWUV treatments except for 15 and $20 \mathrm{~s}$ for MWUV. The colour values $\left(L^{*}, a^{*}, b^{*}\right)$ also increased with treatment time for both MW and MWUV, but no significant $(\mathrm{P}<0.05)$ differences were observed between techniques, except for 15 and $20 \mathrm{~s}$ treatment durations. The differences in $\mathrm{L}^{*}$ values for MW were insignificant $(\mathrm{P}>0.05)$ at 0 and $5 \mathrm{~s}$ and 15 and $20 \mathrm{~s}$. Similar results were observed for MWUV between 15 and $20 \mathrm{~s}$. This may be due to the increase in the fat content after treatment that influenced the major colouring parameter ( $\beta$-carotene) of milk (KNEIFEL et al., 1992; PopovRALJIĆ et al., 2008). 


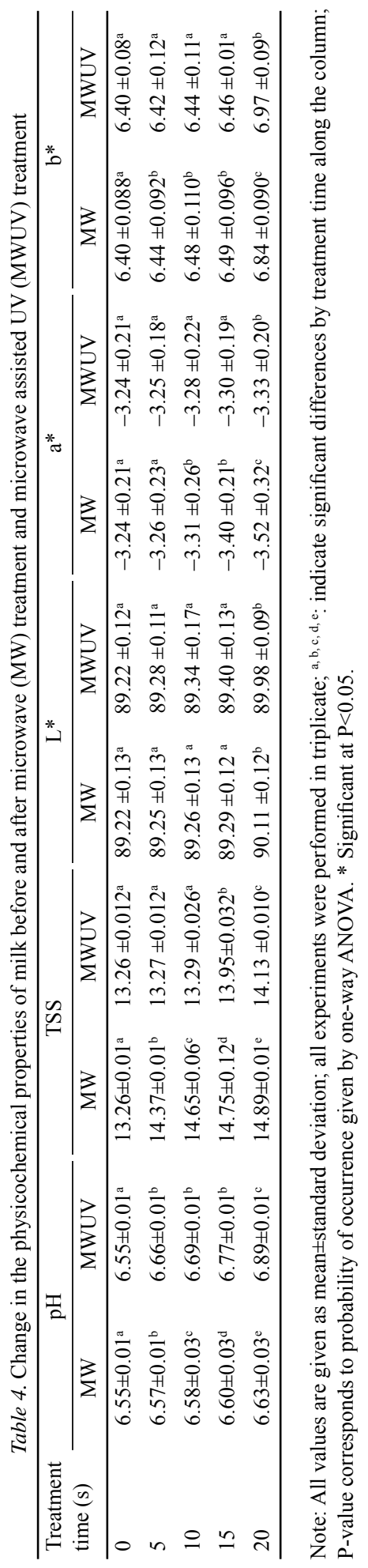




\section{Conclusions}

The microwave-assisted UV system has better sterilization effect compared to microwave only treatment in terms of the microbial load with minimal treatment time. All results were obtained from experiments carried out in a newly developed lab scale microwave-assisted UV sterilization system. The microbial analysis MBRT resulted in higher time values, while MPN and TPC, in terms of microbial load, resulted in lower numbers for microwave assisted UV treatment. The physicochemical values like $\mathrm{pH}$, colour, and TSS of products treated with microwave-assisted UV sterilization system were found to be better than microwave treatment alone in terms of final qualities of the product.

Authors would like to thank the Indian Council of Agricultural Research (ICAR) for providing funding for this project and also would like to thank the National Institute of Technology, Rourkela, Odisha, India.

\section{References}

Aglawe, P.P. \& WadatKar, C.M. (2012): Microbial examination of milk sample from Nagpur region with reference to coliform. Food Sci. Technol. Letters, 3, 24-26.

APHA (1995): Standard methods for the examination of water and wastewater. American Public Health Association, American Water Works Association and Water Environment Federation, Edn. 22.

Anderson, M., Hinds, P., Hurditt, S., Miller, P., Mcgrowder, D. \& Alexander-Lindo, R. (2011): The microbial content of unexpired pasteurized milk from selected supermarkets in a developing country. Asian Pac. J. Trop. Biomed., 1, 205-211.

BANIK, S.K., DAS, K.K. \& UdDIN, M.A. (2015): Microbiological quality analysis of raw, pasteurized, UHT milk samples collected from different locations in Bangladesh. Stamford J. Microbiol., 4, 5-8.

BienVENUE, A., JiMÉNEZ-FloRes, R. \& SinGH, H. (2003): Rheological properties of concentrated skim milk: importance of soluble minerals in the changes in viscosity during storage. J. Dairy Sci., 86, 3813-3821.

CHEN, P.W., CHen, W.C. \& MAO, F.C. (2004): Increase of lactoferrin concentration in mastitis goat milk. J. Vet. Med. Sci., 66, 345-350.

Chye, F.Y., Abdullah, A. \& Ayob, M.K. (2004): Bacteriological quality and safety of raw milk in Malaysia. Food Microbiol., 21, 535-541.

Claeys, W.L., Cardoen, S., Daube, G., De Block, J., Dewettinck, K., Dierick, K., De Zutter, L., Huyghebaert. A., Imberechts, H., Thiange, P. \& Vandenplas, Y. (2013): Raw or heated cow milk consumption: review of risks and benefits. Food Control, 31, 251-262.

Falguera, V., Pagán, J., Garza, S., Garvín, A. \& Ibarz, A. (2011): Ultraviolet processing of liquid food: A review: Part 2: Effects on microorganisms and on food components and properties. Food Res. Int., 44, 1580-1588.

Géczi, G., Horváth, M., Kaszab, T. \& Alemany, G.G. (2013): No major differences found between the effects of microwave-based and conventional heat treatment methods on two different liquid foods. PloS One, 8 , e53720.

Ion-Titapiccolo, G., Alexander, M. \& Corredig, M. (2013): Heating of milk before or after homogenization changes its coagulation behaviour during acidification. Food Biophys., 8, 81-89.

Iwaguch, S., Matsumura, K., Tokuoka, Y., Wakui, S. \& Kawashima, N. (2002): Sterilization system using microwave and UV light. Colloid Surface B., 25, 299-304.

Keyser, M., Müller, I.A., Cilliers, F.P., Nel, W. \& Gouws, P.A. (2008): Ultraviolet radiation as a non-thermal treatment for the inactivation of microorganisms in fruit juice. Innov. Food Sci. Emerg., 9, 348-354.

Kindle, G., Busse, A., Kampa, D., Meyer-Koenig, U. \& Daschner, F.D. (1996): Killing activity of microwaves in milk. J. Hosp. Infect., 33, 273-278.

Kneifel, W., Ulberth, F. \& Schaffer, E. (1992): Tristimulus colour reflectance measurement of milk and dairy products. Lait, 72, 383-391.

Koutchma, T. (2008): UV light for processing foods. Ozone-Sci. Eng., 30, 93-98. 
Maktabi, S., Watson, I. \& PARton, R. (2011): Synergistic effect of UV, laser and microwave radiation or conventional heating on E. coli and on some spoilage and pathogenic bacteria. Innov. Food Sci. Emerg., 12, 129-134.

Mishra, S., Meda, V., Dalai, A.K., Headley, J.V., Peru, K.M. \& Mcmartin, D.W. (2010): Microwave treatment of naphthenic acids in water. J. Environ. Sci. Heal. A., 45, 1240-1247.

Novak, F.R. \& Almeida, J. (2002): Alternative test for the detection of coliforms in milked human milk. J. Pediatr. (Rio J), 78, 193-196.

Omoarukhe, E.D., On-Nom, N., Grandison, A.S. \& Lewis, M.J. (2010): Effects of different calcium salts on properties of milk related to heat stability. Int. J. Dairy Technol., 63, 504-511.

On-Nom, N., Grandison, A.S. \& Lewis, M.J. (2010): Measurement of ionic calcium, pH, and soluble divalent cations in milk at high temperature. J. Dairy Sci., 93, 515-523.

Popov-Raljić, J.V., Lakić, N.S., Laličić-Petronijević, J.G., Barać, M.B. \& Sikimić, V.M. (2008): Colour changes of UHT milk during storage. Sensors, 8, 5961-5974.

Shekhar, S., Joe, J., Kumar, R., Jyothis, J., Kumar, K., Priya, Y.A.R.M. \& Pagote, C.N. (2012): Effect of heat treatment of milk on the sensory and rheological quality of dahi prepared from cow milk. J. Food Dairy Technol., 1, 9-15

Sieber, R., Eberhard, P. \& Gallmann, P.U. (1996): Heat treatment of milk in domestic microwave ovens. Int. Dairy J., 6, 231-246.

TANG, J. (2015): Unlocking potentials of microwaves for food safety and quality. J. Food Sci., 80.

Vanderzant, C. \& Splittstoesser, D.F. (1992): Compendium of methods for the microbiological examination of foods. American Public Health Association (APHA). Washington, USA. 1219 pages.

Walsh, C.D., Guinee, T.P., Reville, W.D., Harrington, D., Murphy, J.J., T O’Kennedy, B. \& Fitzgerald, R.J. (1998): Influence of $\kappa$-casein genetic variant on rennet gel microstructure, cheddar cheese making properties and casein micelle size. Int. Dairy J., 8, 707-714. 